\title{
Preparing Underrepresented Students for Success in Engineering: Results and Lessons Learned from Four Years of the Summer Engineering Institute
}

\section{Dr. Amelito G Enriquez, Canada College}

Amelito Enriquez is a professor of engineering and mathematics at Cañada College. He received his $\mathrm{Ph} . D$. in Mechanical Engineering from the University of California, Irvine. His research interests include technology-enhanced instruction and increasing the representation of female, minority and other underrepresented groups in mathematics, science and engineering.

\section{Prof. Wenshen Pong, San Francisco State University}

Wenshen Pong received his Ph.D. in Structural Engineering from the State University of New York at Buffalo. He joined the School of Engineering at San Francisco State University in 1998. He teaches courses in Civil/Structural Engineering. Dr. Pong is a registered Professional Engineer in California. $\mathrm{He}$ is a member of the American Society of Civil Engineers and the Structural Engineers Association of California. He has published over forty technical papers in the areas of Structural Control and Earthquake Engineering.

\section{Dr. Nilgun Melek Ozer, San Francisco State University}

Nilgun Ozer, Ph. D., is the MESA Engineering Program and Student Resource Center Director for the College of Science and Engineering at San Francisco State University, California. She received her B.S. in Physics from Istanbul University, M.S. in applied physics from Bogazici University, and Ph. D. in Physics from Istanbul University, Istanbul, Turkey.

She joined the faculty of Bogazici University in 1979 and Istanbul Technical University in 1983. Afterwards, she taught undergraduate and graduate level courses in both materials science and physics departments at various universities in Europe and USA. She worked as a staff scientist at Lawrence Berkeley National Laboratory and as a research faculty at UC Berkeley in USA before starting as a MESA Engineering Program director of San Francisco State University in the School of Engineering in 2001.

Her research focuses on the switchable thin film coatings and optical coatings deposited by wet chemical deposition techniques.

She has received UNESCO's awards and honors for her commitment to engineering and engineering education. These include: UNESCO Theresa MacKay Award, 1994; Outstanding female faculty Professor award from UNESCO in 1997, Fulbright Research Fellowship at the University of Florida in Gainesville, 1989-1990; a listing in Cambridge Who's Who in 2011.

She serves as an editorial board member for Solar Energy Materials and Solar Cells, and on the review panel of US Department of Energy since 1998. Dr. Ozer's also serves as faculty advisor for Society of Women Engineers (SWE), Society of Hispanic Professional Engineers (SHPE) and National Society of Black Engineers (NSBE) collegiate chapters.

\section{Hamid Mahmoodi, San Francisco State University}

Hamid Mahmoodi received the B.S. degree in electrical engineering from Iran University of Science and Technology, Tehran, Iran, in 1998 and the M.S. degree in electrical and computer engineering from the University of Tehran, Iran, in 2000. He received his Ph.D. degree in electrical and computer engineering from Purdue University, West Lafayette, IN, in 2005. He is currently an associate professor of electrical and computer engineering in the School of Engineering at San Francisco State University. His research interests include low-power, reliable, and high-performance circuit design for nano-scale technologies. He has many publications in journals and conferences and 5 U.S. patents. He was a recipient of the 2008 SRC Inventor Recognition Award, the 2006 IEEE Circuits and Systems Society VLSI Transactions Best Paper Award, 2005 SRC Technical Excellence Award, and the Best Paper Award of the 2004 International Conference on Computer Design. He is a technical program committee member of International Symposium on Low Power Electronics Design and International Symposium on Quality Electronics Design. 


\section{Dr. Hao Jiang, San Francisco State University}

Hao Jiang received the B.S. degree in materials sciences from Tsinghua University, China, in 1994 and the Ph.D. degree in electrical engineering from the University of California, San Diego, in 2000. Hao Jiang has been with San Francisco State University since August 2007 as an assistant professor in electrical engineering. Prior joining SFSU, he worked for Broadcom Corporation, Jazz Semiconductor and Conexant Systems Inc. His research nterests are in the general area of analog integrated circuits, particularly in ultra-low-power circuits for biomedical applications.

Dr. Cheng Chen, San Francisco State University

Prof. A. S. (Ed) Cheng, San Francisco State University 


\title{
Preparing Underrepresented Students for Success in Engineering: Results and Lessons Learned from Four Years of the Summer Engineering Institute
}

\begin{abstract}
:
Over the last decade, there has been increasingly urgent calls for investment in science and technology education to meet current and future demands for more engineers needed to retain economic competitiveness and innovation capacity of the United States. However, trends in engineering enrollment show that, over the last decade, undergraduate degrees awarded in the fields of engineering have declined from 6.3 to 5.4 percent of the total degrees conferred. An important strategy for increasing the number of future engineers is to engage students from traditionally underrepresented groups in engineering, including women and ethnic minorities. To be successful in expanding the pool of potential engineers, the needs of these underrepresented students have to be addressed. A majority of these students have low-levels of preparation for college-level course work, especially in math and science, and most have little or no pre-college exposure to the engineering profession. In 2009, a small Hispanic-serving community college in the San Francisco Bay Area and a large comprehensive urban university collaborated to develop the Summer Engineering Institute (SEI), which targets female students and underrepresented ethnic minorities. Funded by a grant from the US Department of Education, the SEI is a twoweek residential summer camp that offers students the opportunity to gain insight into the engineering profession and the engineering educational system through a combination of lectures, hands-on laboratory activities, field trips, workshops, panels, and projects. The program also aims to provide students with the skills and resources needed to be successful college students. This paper presents the results and lessons learned from four years of implementation of the SEI, and how the program has succeeded in enhancing interest in engineering among program participants, and in improving persistence and retention among those who have decided to pursue an engineering degree.
\end{abstract}

\section{Introduction}

Despite increasingly urgent calls for investment in science and technology education to meet current and future demands for more engineers needed to retain economic competitiveness and innovation capacity of the United States, trends in engineering enrollment show that, over the last decade, undergraduate degrees awarded in the fields of engineering have declined from 6.3 to 5.4 percent of the total degrees conferred. ${ }^{1}$ An important strategy for increasing the number of future engineers is to engage students from traditionally underrepresented groups in engineering, including Latinos and African Americans. Almost three-fourths of all Latino and two-thirds of all African-American students who go on to higher education begin their postsecondary education in a community college. ${ }^{2}$ Yet for many of these students, the community college gateway does not lead to success. Only one in four students wanting to transfer or earn a degree/certificate did so within six years, according to a recent study of California community colleges. African American and Hispanic students have even lower rates of completion. According to the study, only 14\% of African American students and 20\% of Latino students completed a degree or certificate within six years, compared to $29 \%$ of white students, and $24 \%$ of Asian students. ${ }^{3}$ 
For science and engineering fields, lower success and retention rates for minority students are observed at both community college and university levels resulting in underrepresentation of minority groups in these fields. For instance, while comprising about $28 \%$ of the U.S. population, African Americans and Latinos make up less than $9 \%$ of the individuals who are B.S. or higher-degree holders in the science and engineering fields. ${ }^{4}$ Statistics show that these groups of students tend to enroll in STEM majors in small numbers and have higher attrition rates compared to other groups. ${ }^{5-8}$

The 2012 President's Council of Advisors on Science and Technology (PCAST) report, "Engage to Excel: Producing One Million Additional College Graduates with Degrees in Science, Technology, Engineering, and Mathematics,” indicates that the United States needs to produce one million additional STEM professionals in the next decade in order to retain its historical preeminence in science and technology. ${ }^{9}$ The report proposes that addressing the retention problem in the first two years of college is the most promising and cost-effective strategy to address this need. Strategies that have been proven effective in increasing the retention and success of minority students in science and engineering include introducing context in introductory courses, ${ }^{10}$ capstone courses and projects, ${ }^{11}$ alternative instructional strategies, ${ }^{12}$ and summer programs. ${ }^{13-19}$ Although proven to be a successful strategy particularly for traditionally underserved students, ${ }^{20}$ most residential summer bridge programs focus on incoming college students with primary goals of providing students with an orientation to the campus, building a community among the students, delivering remedial instruction, and providing knowledge and skills for college success. This paper focuses on the Summer Engineering Institute, which is a summer residential program for high school students that is developed collaboratively by a community college and a large, comprehensive urban university to provide students from underrepresented groups the opportunity to explore alternative paths to an engineering career including concurrent enrollment in high school, community college engineering transfer programs, and state universities, as well as private and independent institutions.

\section{The Summer Engineering Institute}

In 2008, Cañada College, a Hispanic-Serving community college in Redwood City, CA, was awarded a Minority Science and Engineering Improvement Program (MSEIP) grant by the US Department of Education. The project, entitled Student On-ramp Leading to Engineering and Sciences (SOLES), aims to maximize the likelihood of success among underrepresented and educationally disadvantaged students interested in pursuing careers in STEM fields by incorporating strategies that address challenges and barriers to recruitment, retention and success of these students. Among the strategies developed for this project is a summer engineering camp developed collaboratively with San Francisco State University (SFSU), a large comprehensive urban university in San Francisco. The Summer Engineering Institute (SEI) is a two-week residential program held on campus at San Francisco State University. The goals of the program are to introduce students to the engineering educational system and the engineering profession, to recruit students into an engineering field, increase student awareness of resources and skills needed for college success, and to increase student knowledge of specific engineering topics. The first year of implementation of SEI was done through a collaboration with the California Department of Transportation (Caltrans), with the curriculum adopted from previous years of implementation of Caltrans' engineering institute. This curriculum focuses mostly on engineering 
fields that are relevant to Caltrans missions, and does not provide students the opportunity to explore the many different pathways to the various engineering career options.

In 2010, the SEI curriculum was drastically revised in order to present a more balanced curriculum that introduces participants to the major areas of engineering. This revised SEI curriculum jointly developed and taught by community college and university engineering faculty features lectures, hands-on workshops, demonstrations, panels, field trips, team-building activities, social events, and group projects. The curriculum introduces students to the engineering education system in California, as well as details on alternative paths to an engineering career including concurrent enrollment in high school, community college engineering transfer programs, and state universities, as well as private and independent institutions. Appendix 1 shows a summary of the typical schedule of the Summer Engineering Institute. This schedule has been adopted with a few minor modifications for the last three years of the program. Most mornings are devoted to lectures and presentations, with group activities and hands-on workshops in the afternoon to reinforce concepts learned from the lectures. Some afternoons are devoted to field trips, and most evenings to working on group projects.

There are four culminating group projects corresponding to each of the four main areas of engineering (civil, computer, electrical, and mechanical), and each student selects two of the four projects. The first week is devoted to completing the first group project, and the second week is for the second project, with group presentations on the last day of the institute. Project group size varies from 3 students to 6 students depending on student interest and the complexity of the project. Groupings for the first and second projects are different, and are based primarily on student interest as expressed on the opening day of the institute. Groups working on the same project are supervised during project time by either a graduate student, or an upper-division student from SFSU who acts as the project mentor. Each project mentor works closely with SFSU faculty in designing the project and planning daily activities related to project completion. Below is an overview of each of the SEI group projects used for the last three years.

\section{Computer Engineering Project: Introducing Computer Engineering via Making an iPhone App}

The computer engineering project is to design and create an iPhone App that has an academic application (e.g, unit conversion, periodic table of elements, math formulas). The goals of this project are to (1) attract high school students into the field of computer engineering, (2) demonstrate the fundamentals of computer engineering, and (3) encourage innovations on designing human-computer interface. The project is carried out in the following four phases:

- Introduce xcode and its emulator: The programming tool, xcode, an object-oriented programming language developed by Apple, is presented to students in a lecture mode. Meanwhile, its emulator, which is used to test the xcode program, is demonstrated.

- Design the App: Each group, which consists of 3-4 students, brainstorms the possible best design for their App. Students will come up with the sketch of the "look" of the App and the flow chart of the program. This process could inspire students' creativity.

- Program and Validation: In this phase, students focus on programming the App using xcode and validate the program using its emulator. Students will be exposed to the reallife computer engineering: programming and debugging. 
- Documentation: Students are asked to report their design and experience. Students are asked to write a clear document on the App their created. Like any engineering project, concise and clear documentation is an integral part of the project.

\section{Civil Engineering Project: Bridge Design}

The SEI Civil Engineering group project has the following objectives:

- Understand the basics of statics and equilibrium of forces.

- Understand static and dynamic loads on structures.

- Understand the basics of truss bridges; use computer applications and simulations to design truss bridges.

- Build a truss bridge using available materials in the PASCO Scientific kit (http://www.pasco.com/).

- Calculate the bar forces of truss bridge under static loads.

- Measure the bar forces of truss bridge under static loads.

- Measure the bar forces of truss bridge under dynamic traffic loads.

- Compare the bar forces under static and dynamic loads.

- Prepare project report and presentation.

\section{Electrical Engineering Project: Mini Timer}

The Electrical Engineering group project uses the BASIC Stamp Activity Kit from Parallax, Inc. (http://www.parallax.com/) to achieve the following objectives:

- Understand basic circuits principles.

- Understand circuit elements, symbols and diagrams.

- Design, build and test simple circuits.

- Understand the basics of microcontrollers.

- Learn concepts of computer hardware and programming.

- Write and debug BASIC programs.

- Prepare project report and presentation.

\section{Mechanical Engineering Project: Build and Test a Small-Scale Stirling Engine}

The Mechanical Engineering group project uses an off-the-shelf Stirling engine kit to achieve the following objectives and activities:

- Understand the fundamentals of heat engines and how they convert energy in the form of heat to mechanical work output.

- Understand the thermodynamic processes in the Stirling engine cycle.

- Work in teams to build a Stirling engine from a commercially available kit, and optimize its operation to provide electrical power output (using a small generator).

- Conduct experiments on the Stirling engine generator to determine energy conversion efficiency (conversion from stored chemical energy in the fuel to electrical energy from the generator).

The project illustrates a practical application of heat engines and demonstrates the magnitude of losses that occur during energy conversion processes. 
In addition to the above culminating projects, SEI also held a variety of workshops related to academic, personal, and professional development. One such workshop provides participants with an overview of renewable energy. Specifically, students learn about the various forms of renewable energy (solar, wind and hydro power), how these forms of energy can be converted into useable (mechanical or electrical) energy, and their pros and cons. Using the Invicta Plastics Renewable Energy kits (http://www.fisher.co.uk/), students observe for themselves the energy conversion processes in action. Students are asked how they would represent the amount of useable energy (mechanical or electrical) as a function of input energy (speed of the wind turbine, or angle of the PV panel with respect to the sun), and then correlate increased output as a result of increased input.

\section{Results from 2009-2012 SEI}

This section is a description of the results of the first four years of implementation of SEI.

\subsection{Recruitment}

Recruitment of SEI participants includes class visits to local area high school math and science courses, presentations to high school math department and counseling department meetings, recruitment tables at college night events for high school students and their parents, and presentations during high school student campus visits and tours. Additionally, program brochures and fliers are sent to high school math and science teachers and to local youth organizations. Program information and application materials are also made available at the program website (http://canadacollege.edu/STEMcenter/highschoolstudents.php).

Table 1 is a summary of the results of the recruitment efforts showing a steadily increasing number of applications, and consequently drastically decreasing acceptance rates. For instance, the acceptance rate in 2009 was $86.2 \%$, compared to only $21.3 \%$ for 2012 . The selection process is based on a number of factors including academic performance, extracurricular activities, statement of interest, participation in high school programs for underrepresented students (e.g., MESA Schools Program [http://mesa.ucop.edu/programs/schoolprogram.html], AVID Program [http://www.avid.org/abo_whatisavid.html]), and letters of recommendation from a math or science instructor, or a counselor. It should be noted that in 2009, all application materials were submitted by mail. Starting 2010, all applications were completed and submitted online. The online submission process has significantly increased the number of applications received and has also simplified the review and selection processes. Although a handful of applications are received from out of state (and even out of the country), the vast majority of applications are from California residents.

Table 1. Summary of applications received and acceptance rates for SEI.

\begin{tabular}{lcccc}
\hline SEI Applications & $\mathbf{2 0 0 9}$ & $\mathbf{2 0 1 0}$ & $\mathbf{2 0 1 1}$ & $\mathbf{2 0 1 2}$ \\
\hline Number of Applicants & 29 & 46 & 77 & 121 \\
Number of Participants & 25 & 26 & 26 & 26 \\
Acceptance Rate & $86.2 \%$ & $56.5 \%$ & $33.8 \%$ & $21.5 \%$ \\
\hline
\end{tabular}




\section{$\underline{3.2}$ Profile of SEI Students}

Since the Summer Engineering Institute was originally funded through the US Department of Education Minority Science and Engineering Improvement Program (MSEIP) whose primary goal is broadening the participation of traditionally underrepresented students in STEM, the project team has made a conscious effort to give priority to minority, female, and first-generation college students, and those from underserved communities. Table 2 shows a summary of the demographics of students selected to participate in the program. The percentage of students from underrepresented minority groups is above $60 \%$ for each year, with Hispanics constituting the largest ethnic group. The percentage of students who are the first in their families to go to college has steadily increased from $44.0 \%$ in 2009 to $73.1 \%$ in 2012. More than half of the participants from each year were female students.

Table 2. Demographics of Summer Engineering Institute participants for 2009 to 2012.

\begin{tabular}{lrrrrrrrr}
\hline & \multicolumn{2}{c}{$\mathbf{2 0 0 9}$} & \multicolumn{2}{c}{$\mathbf{2 0 1 0}$} & $\mathbf{2 0 1 1}$ & \multicolumn{2}{c}{$\mathbf{2 0 1 2}$} \\
\hline Demographics & $\mathbf{N}$ & $\mathbf{\%}$ & $\mathbf{N}$ & $\mathbf{\%}$ & $\mathbf{N}$ & $\mathbf{\%}$ & $\mathbf{N}$ & $\mathbf{\%}$ \\
\hline Gender & & & & & & & & \\
$\quad$ Female & 13 & $52.0 \%$ & 14 & $53.8 \%$ & 15 & $57.7 \%$ & 14 & $53.8 \%$ \\
$\quad$ Male & 12 & $48.0 \%$ & 12 & $46.2 \%$ & 11 & $42.3 \%$ & 12 & $46.2 \%$ \\
$\quad$ Total & 25 & & 26 & & 26 & & 26 & \\
Ethnicity & & & & & & & & \\
$\quad$ African Amer & 3 & $12.0 \%$ & 1 & $3.8 \%$ & 3 & $7.7 \%$ & 3 & $11.5 \%$ \\
American Indian & 0 & $0.0 \%$ & 0 & $0.0 \%$ & 1 & $3.8 \%$ & 1 & $3.8 \%$ \\
Asian American & 5 & $20.0 \%$ & 2 & $7.7 \%$ & 1 & $3.8 \%$ & 4 & $15.4 \%$ \\
Caucasian & 2 & $8.0 \%$ & 3 & $11.5 \%$ & 2 & $7.7 \%$ & 3 & $11.5 \%$ \\
Hispanic & 12 & $48.0 \%$ & 20 & $76.9 \%$ & 18 & $69.2 \%$ & 14 & $53.8 \%$ \\
Pacific Islander & 1 & $4.0 \%$ & 0 & $0.0 \%$ & 1 & $3.8 \%$ & 1 & $3.8 \%$ \\
$\quad$ Other/Unknown & 2 & $8.0 \%$ & 0 & $0.0 \%$ & 0 & $0.0 \%$ & 0 & $0.0 \%$ \\
$\quad$ Total & 25 & & 26 & & 26 & & 26 & \\
First in Family to Attend College? & & & & & & \\
$\quad$ Yes & 11 & $44.0 \%$ & 14 & $53.8 \%$ & 16 & $61.5 \%$ & 19 & $73.1 \%$ \\
$\quad$ No & 14 & $56.0 \%$ & 12 & $46.2 \%$ & 10 & $38.5 \%$ & 7 & $26.9 \%$ \\
$\quad$ Total & 25 & & 26 & & 26 & & 26 & \\
\hline
\end{tabular}

\subsection{SEI Students' Intended Major}

One of the main goals of SEI is to increase the interest of participants in pursuing careers in engineering. To evaluate the success of SEI in achieving this goal, pre- and post-surveys of students' intended major in college were done. Table 3-A summarizes the results of the preprogram survey of students' intended major, while Table 3-B summarizes the post-program 
survey results. Cumulative results for the four years (column labeled "Total") indicate that the largest increase in the number of students' intended major is in Civil Engineering (+9), followed by Mechanical Engineering (+5), and Electrical Engineering (+3). The largest decrease is in Engineering (-11), followed by Undecided (-5), and Computer Engineering (-2). The large decrease in the number of students who initially declared a "general" Engineering major shows that after participating in SEI, these students have been able to identify a specific engineering field of interest to them. These results also indicate that after participating in the program and gaining an understanding of the different engineering fields, several students changed from one area of engineering to another. It is worth noting that, despite a heavy focus on Civil Engineering due to the Caltrans' SEI curriculum used in 2009, the only change in student intended major is one student changing from Civil Engineering to a non-engineering major.

Table 3-A. SEI Pre-Program Student Survey: Intended Major in College.

\begin{tabular}{lccccc}
\hline Pre-Program Intended Major & $\mathbf{2 0 0 9}$ & $\mathbf{2 0 1 0}$ & $\mathbf{2 0 1 1}$ & $\mathbf{2 0 1 2}$ & Total \\
\hline Aerospace Engineering & 0 & 3 & 1 & 1 & 5 \\
Biomedical Engineering & 1 & 0 & 1 & 4 & 6 \\
Chemical Engineering & 0 & 0 & 0 & 1 & 1 \\
Civil Engineering & 4 & 3 & 2 & 2 & 11 \\
Computer Engineering & 2 & 8 & 7 & 5 & 22 \\
Electrical Engineering & 0 & 2 & 0 & 0 & 2 \\
Mechanical Engineering & 3 & 3 & 4 & 1 & 11 \\
Engineering & 7 & 0 & 5 & 9 & 21 \\
Other (non-engineering) & 0 & 2 & 1 & 3 & 6 \\
Undecided & 8 & 5 & 5 & 0 & 18 \\
Total & 25 & 26 & 26 & 26 & 103 \\
\hline
\end{tabular}

Table 3-B. SEI Post-Program Student Survey: Intended Major in College.

\begin{tabular}{lcccccc}
\hline Post-Program Intended Major & $\mathbf{2 0 0 9}$ & $\mathbf{2 0 1 0}$ & $\mathbf{2 0 1 1}$ & $\mathbf{2 0 1 2}$ & Total & Change \\
\hline Aerospace Engineering & 0 & 3 & 0 & 1 & 4 & -1 \\
Biomedical Engineering & 1 & 0 & 1 & 4 & 6 & 0 \\
Chemical Engineering & 0 & 0 & 0 & 0 & 0 & -1 \\
Civil Engineering & 3 & 2 & 7 & 8 & 20 & 9 \\
Computer Engineering & 2 & 7 & 7 & 4 & 20 & -2 \\
Electrical Engineering & 0 & 2 & 0 & 3 & 5 & 3 \\
Mechanical Engineering & 3 & 5 & 6 & 2 & 16 & 5 \\
Engineering & 7 & 0 & 2 & 1 & 10 & -11 \\
Other (non-engineering) & 1 & 5 & 0 & 3 & 9 & 3 \\
Undecided & 8 & 2 & 3 & 0 & 13 & -5 \\
Total & 25 & 26 & 26 & 26 & 103 & $* *$ \\
\hline
\end{tabular}

Another indication of initial student interest in the different areas of engineering is their selection of the culminating projects during SEI. Recall that starting 2010, SEI participants are given a choice of participating in two of the four projects. Table 4-A shows the number of students who 
selected each of the four projects, while Table 4-B shows the number of students who declared each of the four major engineering fields as their major after the program. Note that although only $17.9 \%$ of students indicated initial interest in Civil Engineering by selecting it as one of their SEI projects, 32.1\% of students selected Civil Engineering as their intended major after participating in SEI.

Table 4-A. Summary of the number of SEI students who selected a particular project in 2010, 2011, and 2012.

\begin{tabular}{lccccc}
\hline Project Selected & $\mathbf{2 0 1 0}$ & $\mathbf{2 0 1 1}$ & $\mathbf{2 0 1 2}$ & Total & Percentage \\
\hline Civil Engineering & 7 & 12 & 9 & 28 & $17.9 \%$ \\
Computer Engineering & 19 & 18 & 18 & 55 & $35.3 \%$ \\
Electrical Engineering & 8 & 8 & 11 & 27 & $17.3 \%$ \\
Mechanical Engineering & 18 & 14 & 14 & 46 & $29.5 \%$ \\
Total & 52 & 52 & 52 & 156 & $100.0 \%$ \\
\hline
\end{tabular}

Table 4-B. Summary of post-SEI intended majors (only includes one of the four major areas of engineering).

\begin{tabular}{lccccc}
\hline Post-SEI Intended Major & $\mathbf{2 0 1 0}$ & $\mathbf{2 0 1 1}$ & $\mathbf{2 0 1 2}$ & Total & Percentage \\
\hline Civil Engineering & 2 & 7 & 8 & 17 & $32.1 \%$ \\
Computer Engineering & 7 & 7 & 4 & 18 & $34.0 \%$ \\
Electrical Engineering & 2 & 0 & 3 & 5 & $9.4 \%$ \\
Mechanical Engineering & 5 & 6 & 2 & 13 & $24.5 \%$ \\
Total & 16 & 20 & 17 & 53 & $100.0 \%$ \\
\hline
\end{tabular}

\subsection{Student Survey Results: Student Attitudes Towards SEI}

To assess the effects of participation in SEI on student attitudes about engineering, their confidence in succeeding in college, and SEI's impact on their selection of an engineering major, pre- and post- program surveys were administered. The surveys include items in which students responses are in the following Likert scale: 5 - Strongly Agree, 4 - Agree, 3 - Neutral, 2 Disagree, 1 - Strongly Disagree. Averages of responses were calculated and results are summarized in Table 5-A for 2009, Table 5-B for 2010, Table 5-C for 2011, and Table 5-D for 2012.

With respect to the prompt "I feel excited about participating in the Summer Engineering Institute," student responses were highly positive, with averages between "Agree" and "Strongly Agree." Statistically significant increases from pre- to post- program responses were measured in 2009 and 2011. With respect to students' confidence in succeeding in college, statistically significant improvement in the post-program student responses is observed in 2011. With respect to the prompt "I am confident that SEI will help me in selecting an appropriate Engineering 
major," a decrease in the average student response is observed for each of the four years, with the largest (and the only statistically significant decrease) observed in 2009. This is perhaps due to the nature of the 2009 SEI curriculum, which focused mostly on Civil Engineering, and hence failed to be help students in selecting an appropriate major.

Table 5-A. 2009 SEI Student Survey: Attitudes towards SEI. Response Scale: 5 - Strongly Agree, 4 - Agree, 3 - Neutral, 2 - Disagree, 1 - Strongly Disagree.

\begin{tabular}{|c|c|c|c|}
\hline Attitudes & Pre & Post & Change \\
\hline $\begin{array}{l}\text { I feel excited about participating in the Summer } \\
\text { Engineering Institute. }\end{array}$ & 4.24 & 4.58 & $0.34 *$ \\
\hline $\begin{array}{l}\text { I am confident that I have the skills and academic } \\
\text { preparation to be a successful college student. }\end{array}$ & 4.32 & 4.42 & 0.10 \\
\hline $\begin{array}{l}\text { I am confident that SEI will help me in selecting an } \\
\text { appropriate Engineering major. }\end{array}$ & 4.16 & 3.63 & $-0.54 *$ \\
\hline
\end{tabular}

Table 5-B. 2010 SEI Student Survey: Attitudes towards SEI.

\begin{tabular}{|c|c|c|c|}
\hline Attitudes & Pre & Post & Change \\
\hline I feel excited about participating in Summer & & & \\
\hline Engineering Institute. & 4.35 & 4.23 & -0.12 \\
\hline I am confident that I have the skills and academic & 4.00 & 4.12 & 0.12 \\
\hline $\begin{array}{l}\text { I am confident that SEI will help me in selecting an } \\
\text { appropriate Engineering major. }\end{array}$ & 4.19 & 3.81 & -0.38 \\
\hline
\end{tabular}

For the 2011 and 2012 student surveys, the prompt "As a result of SEI, I am now more likely to consider science or engineering as a major in college," was added. Responses to this have been very positive, with average values of 4.54 for 2011 and 4.63 for 2012 (last row of Table 5-C and Table 5-D).

Table 5-C. 2011 SEI Student Survey: Attitudes towards SEI.

\begin{tabular}{|c|c|c|c|}
\hline Attitudes & Pre & Post & Change \\
\hline $\begin{array}{l}\text { I feel excited about participating in Summer } \\
\text { Engineering Institute. }\end{array}$ & 4.38 & 4.83 & $0.45^{*}$ \\
\hline $\begin{array}{l}\text { I am confident that I have the skills and academic } \\
\text { preparation to be a successful college student. }\end{array}$ & 4.35 & 4.71 & $0.36^{*}$ \\
\hline $\begin{array}{l}\text { I am confident that SEI will help me in selecting an } \\
\text { appropriate Engineering major. }\end{array}$ & 4.42 & 4.38 & -0.04 \\
\hline $\begin{array}{l}\text { As a result of SEI, I am now more likely to consider } \\
\text { science or engineering as a major in college. }\end{array}$ & -- & 4.54 & -- \\
\hline
\end{tabular}


Table 5-D. 2012 SEI Student Survey: Attitudes towards SEI.

\begin{tabular}{lccc}
\hline Attitudes & Pre & Post & Change \\
\hline $\begin{array}{l}\text { I feel excited about participating in Summer } \\
\begin{array}{l}\text { Engineering Institute. } \\
\text { I am confident that I have the skills and academic } \\
\text { preparation to be a successful college student. }\end{array}\end{array}$ & 4.35 & 4.50 & 0.15 \\
$\begin{array}{l}\text { I am confident that SEI will help me in selecting an } \\
\text { appropriate Engineering major. }\end{array}$ & 4.31 & 4.17 & -0.02 \\
$\begin{array}{l}\text { As a result of participating in the SEI, I am now } \\
\text { more likely to consider science or engineering as a } \\
\text { major in college. }\end{array}$ & -- & 4.63 & -0.32 \\
\hline
\end{tabular}

\section{$\underline{\text { 3.5 Student Survey Results: College Success Skills }}$}

With regards to SEI's goal of increasing students' awareness of knowledge and skills that are important for college success, the results of pre- and post-SEI student surveys are summarized in Table 6-A for 2009, Table 6-B for 2010, Table 6-C for 2011, and Table 6-D for 2012. The survey prompt was: "How much do you know about each of the following?". And the Response Scale was: 5 - A Lot, 4 - Quite a Bit, 3 - Some, 2 - A little, 1 - Nothing. For 2009, the preprogram survey average responses were mostly between "Some" and "Quite a Bit". For the postprogram survey, slight (and statistically insignificant) increases were observed for each item except "Using a calculator for Engineering Calculations" where the increase is statistically significant. For subsequent years, statistically significant gains were observed for Financial Aid and Exploring Majors in 2010; Essay Writing, Exploring Majors, and Using a Calculator in 2011; and five separate areas (Learning Styles, Financial Aid, Essay Writing, Exploring Majors, and Using a Calculator) in 2012.

Table 6-A. 2009 SEI Student Survey: Knowledge and Skills Important for College Success. Response Scale: 5 - A Lot, 4 - Quite a Bit, 3 - Some, 2 - A little, 1 - Nothing.

\begin{tabular}{lccc}
\hline Knowledge and Skills for College Success & Pre & Post & Change \\
\hline Time management & 3.72 & 3.96 & 0.24 \\
Education planning & 3.80 & 3.83 & 0.03 \\
Your learning style & 3.60 & 3.83 & 0.23 \\
Your personal strengths & 3.76 & 4.00 & 0.24 \\
Self Confidence & 3.92 & 4.13 & 0.21 \\
Essay writing & 3.36 & 3.38 & 0.02 \\
How to transfer and explore majors & 2.80 & 2.92 & 0.12 \\
Using a calculator for Engineering Calculations & 3.04 & 3.67 & $0.63^{*}$ \\
\hline
\end{tabular}

$$
\text { * The change is statistically significant }(p<0.050) \text {. }
$$


Table 6-B. 2010 SEI Student Survey: Knowledge and Skills Important for College Success.

\begin{tabular}{lccc}
\hline Knowledge and Skills for College Success & Pre & Post & Change \\
\hline Time management & 3.62 & 3.96 & 0.34 \\
Education planning & 3.46 & 3.88 & 0.42 \\
Your learning style & 3.69 & 3.92 & 0.23 \\
Your personal strengths & 3.88 & 3.81 & -0.07 \\
Financial Aid & 3.08 & 3.62 & $0.54^{*}$ \\
Self Confidence & 3.81 & 3.73 & -0.08 \\
Essay writing & 3.65 & 3.92 & 0.27 \\
How to transfer and explore majors & 2.50 & 3.31 & $0.81^{* *}$ \\
Using a calculator for Engineering Calculations & 2.65 & 3.08 & 0.42 \\
\hline
\end{tabular}

* The change is statistically significant $(p<0.050)$.

** The change is statistically significant $(p<0.010)$.

Table 6-C. 2011 SEI Student Survey: Knowledge and Skills Important for College Success.

\begin{tabular}{lccc}
\hline Knowledge and Skills for College Success & Pre & Post & Change \\
\hline Time management & 4.04 & 4.29 & 0.25 \\
Education planning & 3.88 & 4.08 & 0.20 \\
Your learning style & 4.04 & 4.17 & 0.13 \\
Your personal strengths & 4.19 & 4.25 & 0.06 \\
Financial Aid & 3.73 & 4.17 & 0.44 \\
Self Confidence & 4.15 & 4.17 & 0.01 \\
Essay writing & 3.31 & 3.88 & $0.57 *$ \\
How to transfer and explore majors & 2.73 & 3.42 & $0.69 *$ \\
Using a calculator for Engineering Calculations & 2.92 & 3.58 & $0.66^{*}$ \\
\hline
\end{tabular}

* The change is statistically significant $(p<0.050)$.

Table 6-D. 2012 SEI Student Survey: Knowledge and Skills Important for College Success.

\begin{tabular}{lccc}
\hline Knowledge and Skills for College Success & Pre & Post & Change \\
\hline Time management & 3.77 & 4.21 & 0.44 \\
Education planning & 3.65 & 4.08 & 0.43 \\
Your learning style & 3.73 & 4.33 & $0.60^{*}$ \\
Your personal strengths & 4.00 & 4.13 & 0.13 \\
Financial Aid & 3.08 & 4.00 & $0.92^{* *}$ \\
Self Confidence & 3.77 & 4.04 & 0.27 \\
Essay writing & 3.46 & 4.29 & $0.83^{* *}$ \\
How to transfer and explore majors & 2.73 & 3.58 & $0.85^{* *}$ \\
Using a calculator for Engineering Calculations & 2.12 & 3.50 & $1.38^{* * *}$ \\
\hline
\end{tabular}

* The change is statistically significant $(p<0.050)$.

** The change is statistically significant $(p<0.010)$.

$* * *$ The change is statistically significant $(p<0.001)$. 


\subsection{Student Survey Results: College Resources and Support Services}

With regards to the SEI program goal of increasing student knowledge of available college resources and support services, results of the student surveys are shown in Table 7-A to Table 7D when students were given the prompt: "How much do you know about each of the following?". For the 2009 results, there is no statistically significant change in the average responses in any of the areas after the completion of SEI. In contrast, statistically significant increases in the average response for the post-program survey are observed in all but one area for both the 2010 and 2012 results. For 2011, statistically significant gains are observed in the areas of Tutorial Center, Transfer Center and MESA.

Table 7-A. 2009 SEI Student Survey: Knowledge of College Resources and Support Services. Response Scale: 5 - A Lot, 4 - Quite a Bit, 3 - Some, 2 - A little, 1 - Nothing.

\begin{tabular}{lccc}
\hline Knowledge of Resources and Support Services & Pre & Post & Change \\
\hline Library & 3.16 & 3.50 & 0.34 \\
Undergraduate Advising & 2.56 & 2.67 & 0.11 \\
Learning center & 2.88 & 3.17 & 0.29 \\
Health center & 2.60 & 2.71 & 0.11 \\
Psychological services & 2.20 & 2.29 & 0.09 \\
Tutorial services & 2.88 & 2.96 & 0.08 \\
Financial aid office & 3.04 & 2.75 & -0.29 \\
Transfer center & 2.32 & 2.38 & 0.06 \\
Disabled student services & 1.88 & 1.96 & 0.08 \\
MESA & 2.96 & 3.08 & 0.12 \\
\hline
\end{tabular}

Table 7-B. 2010 SEI Student Survey: Knowledge of College Resources and Support Services.

\begin{tabular}{lccc}
\hline Knowledge of Resources and Support Services & Pre & Post & Change \\
\hline Library & 3.19 & 3.69 & 0.50 \\
Undergraduate Advising & 2.77 & 3.42 & $0.65^{* *}$ \\
Learning center & 2.81 & 3.65 & $0.84^{* *}$ \\
Health center & 2.38 & 3.35 & $0.97^{* * *}$ \\
Tutorial services & 2.50 & 3.69 & $1.19^{* * *}$ \\
Financial aid office & 2.69 & 3.69 & $1.00^{* * *}$ \\
Transfer center & 2.35 & 3.08 & $0.73^{* *}$ \\
Disabled student services & 1.77 & 2.58 & $0.81^{* *}$ \\
MESA & 2.27 & 3.62 & $1.35^{* * *}$ \\
\hline
\end{tabular}

* The change is statistically significant $(p<0.050)$.

** The change is statistically significant $(p<0.010)$.

$* * *$ The change is statistically significant $(p<0.001)$. 
Table 7-C. 2011 SEI Student Survey: Knowledge of College Resources and Support Services.

\begin{tabular}{lccc}
\hline Knowledge of Resources and Support Services & Pre & Post & Change \\
\hline Library & 3.54 & 3.88 & 0.34 \\
Undergraduate Advising & 3.35 & 3.88 & 0.53 \\
Learning center & 3.77 & 3.96 & 0.19 \\
Health center & 3.31 & 3.63 & 0.32 \\
Tutorial services & 3.04 & 3.71 & $0.67 *$ \\
Financial aid office & 3.46 & 3.96 & 0.50 \\
Transfer center & 2.35 & 3.04 & $0.70^{*}$ \\
Disabled student services & 1.96 & 2.46 & 0.50 \\
MESA & 2.65 & 4.20 & $1.55^{* * *}$ \\
\hline$\quad$ The change is statistically significant $(p<0.050)$. & & \\
$\quad * *$ The change is statistically significant $(p<0.010)$. & & \\
$\quad * * *$ The change is statistically significant $(p<0.001)$. & &
\end{tabular}

Table 7-D. 2012 SEI Student Survey: Knowledge of College Resources and Support Services.

\begin{tabular}{lccc}
\hline Knowledge of Resources and Support Services & Pre & Post & Change \\
\hline Library & 3.19 & 3.63 & 0.44 \\
Undergraduate Advising & 2.77 & 3.67 & $0.90^{* *}$ \\
Learning center & 2.46 & 3.42 & $0.96^{* *}$ \\
Health center & 2.46 & 3.29 & $0.83^{*}$ \\
Tutorial services & 2.65 & 3.42 & $0.76^{*}$ \\
Financial aid office & 2.50 & 3.79 & $1.29^{* * *}$ \\
Transfer center & 1.85 & 3.04 & $1.20^{* * *}$ \\
Disabled student services & 1.58 & 2.38 & $0.80^{*}$ \\
MESA & 1.92 & 3.38 & $1.46^{* * *}$ \\
\hline
\end{tabular}

* The change is statistically significant $(p<0.050)$.

** The change is statistically significant $(p<0.010)$.

$* * *$ The change is statistically significant $(p<0.001)$.

\subsection{Student Survey Results: Knowledge of Specific Engineering Topics}

Another major goal of the Summer Engineering Institute is to increase student awareness of the engineering educational system and the profession by increasing student knowledge of specific engineering topics. To assess the success of the program in achieving this goal, pre- and postprogram surveys include questions about student knowledge of specific engineering topics. The results are summarized in Table 8-A for 2009, Table 8-B for 2010, Table 8-C for 2011, and Table 8-D for 2012. Note that since the SEI curriculum was drastically changed in 2010, the engineering topics listed in the 2009 survey were very different from those listed in 2010, 2011, and 2012. For the 2009 responses, statistically significant gains in all but one subject area (CAD) is observed. On the other hand, for 2010-2012 results, statistically significant gains are observed for all topics. Furthermore, in contrast with the 2009 post-program responses where many of the 
averages responses remained below 3.00, almost all of the average responses are above 3.00 for 2010-2012. Also, for the 2009 responses, the most significant gains were in topics that are related to Civil Engineering. This is attributed to the narrow focus of the 2009 SEI curriculum.

Table 8-A. 2009 SEI Student Survey: Knowledge of Specific Engineering Topics. Response Scale: 5 - A Lot, 4 - Quite a Bit, 3 - Some, 2 - A little, 1 - Nothing.

\begin{tabular}{|c|c|c|c|}
\hline Knowledge of Specific Engineering Topics & Pre & Post & Change \\
\hline Computer-Aided Design (CAD) & 2.28 & 2.46 & 0.18 \\
\hline Laboratory Experimental Procedures & 2.16 & 2.67 & $0.51 *$ \\
\hline Robotics & 2.04 & 2.79 & $0.75 *$ \\
\hline Computer Engineering & 2.04 & 2.92 & $0.88 * *$ \\
\hline Electronics and Electrical Engineering & 2.40 & 3.29 & $0.89 * *$ \\
\hline Geotechnical Engineering & 1.72 & 2.83 & $1.11^{* * *}$ \\
\hline Hydraulics & 1.76 & 2.88 & $1.12 * * *$ \\
\hline Data Analysis & 2.24 & 3.38 & $1.14^{* * *}$ \\
\hline Bridge Design & 2.16 & 3.38 & $1.22 * * *$ \\
\hline Engineering Design Process & 2.20 & 3.79 & $1.59 * * *$ \\
\hline Surveying and Map Reading & 2.20 & 3.88 & $1.68 * * *$ \\
\hline
\end{tabular}

Table 8-B. 2010 SEI Student Survey: Knowledge of Specific Engineering Topics.

\begin{tabular}{llcc}
\hline Knowledge of Specific Engineering Topics & Pre & Post & Change \\
\hline Computer-Aided Design (CAD) & 1.73 & 2.77 & $1.04^{* * *}$ \\
Laboratory Experimental Procedures & 2.00 & 3.15 & $1.15^{* * *}$ \\
Data Analysis & 2.04 & 3.23 & $1.19^{* * *}$ \\
Engineering Design Process & 1.85 & 3.54 & $1.69^{* * *}$ \\
Civil Engineering & 1.69 & 3.77 & $2.08^{* * *}$ \\
Computer Engineering & 1.96 & 3.96 & $2.00^{* * *}$ \\
Electrical Engineering & 1.77 & 3.54 & $1.77^{* * *}$ \\
Mechanical Engineering & 2.00 & 4.00 & $2.00^{* * *}$ \\
Robotics & 1.69 & 3.77 & $2.08^{* * *}$ \\
Renewable Energy & 1.92 & 3.65 & $1.73^{* * *}$ \\
Computer Programming & 1.81 & 3.77 & $1.96^{* * *}$ \\
Bridge Design & 1.50 & 3.46 & $1.96^{* * *}$ \\
Thermodynamics & 1.62 & 3.62 & $2.00^{* * *}$ \\
Electronics & 2.08 & 3.54 & $1.46^{* * *}$ \\
\hline
\end{tabular}

* The change is statistically significant $(p<0.050)$.

** The change is statistically significant $(p<0.010)$.

$* * *$ The change is statistically significant $(p<0.001)$. 
Table 8-C. 2011 SEI Student Survey: Knowledge of Specific Engineering Topics.

\begin{tabular}{lccc}
\hline Knowledge of Specific Engineering Topics & Pre & Post & Change \\
\hline Computer-Aided Design (CAD) & 1.92 & 3.46 & $1.54^{* * *}$ \\
Laboratory Experimental Procedures & 2.38 & 3.33 & $0.95^{* *}$ \\
Data Analysis & 2.77 & 3.67 & $0.90^{* *}$ \\
Engineering Design Process & 2.12 & 4.04 & $1.93^{* * *}$ \\
Civil Engineering & 2.27 & 3.88 & $1.61^{* * *}$ \\
Computer Engineering & 2.81 & 4.00 & $1.19^{* * *}$ \\
Electrical Engineering & 2.35 & 3.71 & $1.36^{* * *}$ \\
Mechanical Engineering & 2.38 & 3.92 & $1.53^{* * *}$ \\
Robotics & 2.23 & 4.00 & $1.77^{* * *}$ \\
Renewable Energy & 2.15 & 4.13 & $1.97^{* * *}$ \\
Computer Programming & 2.42 & 3.88 & $1.45^{* * *}$ \\
Bridge Design & 1.96 & 3.88 & $1.91^{* * *}$ \\
Thermodynamics & 1.92 & 3.71 & $1.79^{* * *}$ \\
Electronics & 2.62 & 3.79 & $1.18^{* * *}$ \\
\hline$\quad$ The change is statistically significant $(p<0.050)$. & & \\
$\quad * *$ The change is statistically significant $(p<0.010)$. & &
\end{tabular}

Table 8-D. 2012 SEI Student Survey: Knowledge of Specific Engineering Topics.

\begin{tabular}{lccc}
\hline Knowledge of Specific Engineering Topics & Pre & Post & Change \\
\hline Computer-Aided Design (CAD) & 1.58 & 2.96 & $1.38^{* * *}$ \\
Laboratory Experimental Procedures & 2.19 & 3.33 & $1.14^{* *}$ \\
Data Analysis & 2.46 & 3.50 & $1.04^{* *}$ \\
Engineering Design Process & 1.96 & 3.58 & $1.62^{* * *}$ \\
Civil Engineering & 2.04 & 3.67 & $1.63^{* * *}$ \\
Computer Engineering & 2.38 & 3.63 & $1.24^{* * *}$ \\
Electrical Engineering & 2.12 & 3.75 & $1.63^{* * *}$ \\
Mechanical Engineering & 2.31 & 3.71 & $1.40^{* * *}$ \\
Robotics & 2.23 & 3.83 & $1.60^{* * *}$ \\
Renewable Energy & 2.12 & 3.83 & $1.72^{* * *}$ \\
Computer Programming & 2.12 & 3.67 & $1.55^{* * *}$ \\
Bridge Design & 2.19 & 3.67 & $1.47^{* * *}$ \\
Thermodynamics & 1.92 & 3.33 & $1.41^{* * *}$ \\
Electronics & 2.62 & 3.58 & $0.97^{* *}$ \\
\hline
\end{tabular}

* The change is statistically significant $(p<0.050)$.

$* *$ The change is statistically significant $(p<0.010)$.

$* * *$ The change is statistically significant $(p<0.001)$. 


\subsection{Student Survey Results: 20010-2012 Program Activities}

In order to establish a more direct comparison of the SEI activities in 2010, 2011, and 2012, the results of the post-program survey of their usefulness are summarized. The post-program survey had the prompt: " How useful is each following?" and the Response Scale was: 5 - A Lot, 4 Quite a Bit, 3 - Some, 2 - A little, 1 - Not at All Useful. Note that survey results from 2009 are not included in the present analysis because the curriculum in 2009 (and consequently the activities) was very different because it was based on the curriculum previously developed by Caltrans.

Table 9 is a summary of the average student ratings of the usefulness of the projects. Steady improvements of the ratings of the projects are observed over the past three years, with the exception of the 2012 iPhone Project. Yearly increases in student ratings of the project can be attributed to the program improvements made as a result of lessons learned from previous years. For the 2012 iPhone project, the low student average rating is brought about by the combination of technical difficulties (old computers not working properly with the software) and a last-minute switch to a graduate student mentor who does not have a solid background in iPhone Apps.

Table 9. Student Ratings of the Usefulness of SEI Projects. Response Scale: 5 - A Lot, 4 - Quite a Bit, 3 - Some, 2 - A little, 1 - Not at All Useful.

\begin{tabular}{lccc}
\hline Projects & $\mathbf{2 0 1 0}$ & $\mathbf{2 0 1 1}$ & $\mathbf{2 0 1 2}$ \\
\hline Bridge design & 4.00 & 4.33 & 4.70 \\
Designing a Timer & 4.27 & 4.33 & 4.72 \\
iPhone project & 4.10 & 4.65 & 3.81 \\
Sterling Engine & 4.26 & 4.60 & 4.75 \\
\hline
\end{tabular}

Table 10. Student Ratings of the Usefulness of Lectures and Presentations. Response Scale: 5 A Lot, 4 - Quite a Bit, 3 - Some, 2 - A little, 1 - Not at All Useful.

\begin{tabular}{lccc}
\hline Lectures & $\mathbf{2 0 1 0}$ & $\mathbf{2 0 1 1}$ & $\mathbf{2 0 1 2}$ \\
\hline Lecture on Civil Engineering & 3.65 & 4.21 & 4.26 \\
Lecture on Computer Engineering & 3.69 & 4.25 & 3.74 \\
Lecture on Electrical Engineering & 3.23 & 4.00 & 3.87 \\
Lecture on Mechanical Engineering & 3.69 & 4.08 & 4.22 \\
Overview of Engineering Curriculum and Profession & 3.46 & 4.33 & 4.17 \\
Top 10 Things Engineering Students Need to Know & 4.35 & 4.46 & 4.39 \\
Wheel Chair Lab presentation & 3.88 & 4.38 & 4.17 \\
Professionalism and Ethics & 3.73 & 4.50 & 4.52 \\
Panel of Engineers & 3.58 & 4.25 & 4.26 \\
\hline
\end{tabular}

Table 10 is a summary of the average student ratings of the usefulness of the SEI lectures. Ratings for 2011 improved over those of 2010 but decreased slightly for 2012. The slight dip in 2012 may be attributed to the fact that for the 2012 SEI, the participants were high school 
sophomores and juniors as opposed to juniors and seniors for the previous years. As a result, some of the lectures could have been at a level that is slightly above the students' level of understanding. This will be factor taken into account in future SEI programs, which will continue to focus on high school sophomores and juniors.

Table 11. Student Ratings of the Usefulness of Workshops. Response Scale: 5 - A Lot, 4 - Quite a Bit, 3 - Some, 2 - A little, 1 - Not at All Useful.

\begin{tabular}{lccc}
\hline Workshops & $\mathbf{2 0 1 0}$ & $\mathbf{2 0 1 1}$ & $\mathbf{2 0 1 2}$ \\
\hline Guaranteed 4.0 workshop & 3.96 & $*$ & $*$ \\
Civil Engineering Workshop & 3.77 & 4.33 & 4.09 \\
Egg Drop & 4.12 & 4.25 & 4.17 \\
Secret Codes with Tic Tacs & 4.12 & 4.17 & 4.04 \\
Renewable Energy & 2.54 & 4.04 & 3.91 \\
Robotics Workshop & 4.08 & 4.38 & 4.43 \\
Math Review using MyMathTest & 4.15 & 4.07 & 3.88 \\
Resume Workshop & 3.46 & $*$ & 4.04 \\
Vision Board & 4.00 & $*$ & $*$ \\
Toast Masters & $*$ & $*$ & 3.92 \\
Robotics Challenge & 4.19 & 4.17 & 4.38 \\
NASA CIPAIR Interns (Civil Engineering) & $*$ & 4.42 & 4.13 \\
NASA CIPAIR Interns (Computer Engineering) & $*$ & 4.38 & 4.13 \\
NASA CIPAIR Interns (Electrical Engineering) & $*$ & 4.33 & 4.04 \\
Field Trip: Shipyard (2010), PG\&E (2011 \& 2012) & 3.96 & 4.42 & 4.43 \\
Field Trip: Exploratorium & 4.31 & 4.50 & 4.52 \\
Field Trip: Bay Bridge & 3.91 & 4.75 & 4.79 \\
\hline
\end{tabular}

*Workshop was not offered.

Table 11 shows a summary of average student ratings of the usefulness of the workshops. Note that not all of the workshops were offered during each of the years. Just like the lectures, ratings for all the workshops improved significantly from 2009 to 2010, and decreased slightly from 2011 to 2012 for some of the workshops. Student ratings of the field trips (last three rows of Table 11) have shown steady improvements of the years, and have become some of the most highly rated activities in the institute.

\section{SEI Long-Term Impact: Follow-up Survey for 2009-2011 SEI Graduates}

In fall 2012, a follow up survey was administered to graduates of the Summer Engineering Institute. Only students who participated in the 2009, 2010, and 2011 are included in the survey since 2012 attendees have just completed the institute the previous summer. The purpose of the survey is to determine students current educational status (whether or not they are still attending school), the major that they are currently pursuing or are intending to pursue, and whether or not 
attending the SEI has made any impact in their educational and career goals. The survey notification was sent by email and completed online.

A summary of the survey results is given below:

- $\quad$ Out of the 77 SEI graduates targeted by the survey (25 for 2009, and 26 each for 2010 and 2011), 40 students responded. This corresponds to a response rate of 52\%. Unfortunately, several of the email addresses used are no longer current, and the survey invitation sent by email bounced back.

- All 40 of the survey respondents are still in school; 38 are college students, and 2 are still high school students.

- Out of the 40 respondents, 33 (or 82.5\%) are pursuing an engineering major, 6 are pursuing non-engineering majors, and one is undecided.

The percentage of survey respondents who are majoring in engineering (82.5\%) compares favorably with the percentage of students who declared one of the engineering fields immediately following the SEI. From Table 3-B (Section 3.3 of this paper), 58 out of the 77 2009-2011 SEI graduates (or 75.3\%) indicated an engineering major in the post-program survey. The 58 students intending to pursue an engineering degree include 16 from 2009, 19 from 2010, and 23 from 2011.

The fall 2012 follow-up survey also attempts to determine student attitudes towards SEI and whether or not participation in the program has an impact on the career path they have chosen. Student responses are summarized in Table 12. When asked how much they agree with the statement "I enjoyed participating in the Summer Engineering Institute," the average response is 4.80. The average response for engineering majors (4.82) is slightly higher than those who are non-engineering majors or undecided (4.71). With respect to the prompt "My participation in SEI has a significant impact on my choice of career," the average response is 4.15. Understandably, there is a significant difference in the average response for the engineers (4.33, which is between "Agree" and "Strongly Disagree") and the average response for non-engineers (3.29, which is close to "Neutral"). As a whole, the SEI is viewed very positively by the students, and has had a significant influence in students' choice of majors, especially those who decided to pursue a major in engineering.

Table 12. SEI Follow-up Survey: Student Attitudes Towards SEI. Response Scale: 5 - Strongly Agree, 4 - Agree, 3 - Neutral, 2 - Disagree, 1 - Strongly Disagree.

\begin{tabular}{|c|c|c|c|}
\hline Follow-up Survey Prompt & $\begin{array}{l}\text { Engineers } \\
(\mathrm{N}=33)\end{array}$ & $\begin{array}{l}\text { Non-Engineers } \\
(\mathbf{N}=7)\end{array}$ & $\begin{array}{c}\text { All } \\
(\mathrm{N}=40)\end{array}$ \\
\hline $\begin{array}{l}\text { I enjoyed participating in the Summer } \\
\text { Engineering Institute. }\end{array}$ & 4.82 & 4.71 & 4.80 \\
\hline $\begin{array}{l}\text { My participation in SEI has a significant } \\
\text { impact on my choice of career. }\end{array}$ & 4.33 & 3.29 & 4.15 \\
\hline
\end{tabular}




\section{Summary and Conclusions}

The collaborative work done by two completely different types of institution-Cañada College, which a community college, and San Francisco State University, which is a large comprehensive urban university - has resulted in the success of the Summer Engineering Institute as a unique program that provides high school students an opportunity to explore the engineering profession and the various pathways to an engineering career. Since it was first implemented in 2009, the Summer Engineering Institute has been successful in achieving most of its goals. The levels of program participation among female students, students from traditionally underrepresented groups, and students who are the first in their families to go to college have been high. The program has been successful in increasing the interest of participants in pursuing careers in engineering as indicated by pre- and post-program surveys. By providing the participants the opportunity to explore the major fields of engineering and increase their knowledge of specific engineering topics, as well as understand the many different pathways to an engineering career, the program has been successful in helping students make a better decision on whether or not pursue engineering as a career, and which particular field of engineering is most suited for them. Among students who solidified their choice of an engineering career and decided to major in one of the engineering fields, the program has provided context to their study of engineering - a strategy that has been proven to increase student motivation and persistence, especially as they struggle through the first two years of their engineering studies.

The program has also been successful in increasing student knowledge of skills needed to succeed in college, as well as the resources and support services available on campus to help them achieve their educational goals. As a result, students expressed increased self-efficacy in succeeding in college. Students also expressed satisfaction with the program as a whole, and its success in meeting their expectations. Students' opinions of the activities, workshops and projects done during the institute have been very positive, and have been improving over the last four years. The changes in the curriculum that have been implemented from one year to the next have been viewed very positively by SEI students, faculty and staff. The quality of student work, especially on the culminating projects, have also been steadily improving.

The fall 2012 follow-up survey given to the graduates of the first three years (2009-2011) of the institute has revealed the long-term positive impact of SEI on its participants. All the survey respondents are still attending school, and a vast majority of them are pursuing an engineering major. More than a year after attending the institute, students have an even high opinion of the positive experience they had during the program. SEI graduates who are currently pursuing a degree in engineering attribute their participation in the program to having a significant influence in their choice of major.

Cañada College and San Francisco State University plan to continue offering the program for the next four years through funding from the US Department of Education Hispanic Serving Institution Science, Technology, Engineering, and Mathematics (HSI STEM) grant. Program activities will continue to be improved based on feedback from students, faculty, and SEI staff, as well as recent changes in the engineering curriculum. Program personnel will work even more closely with local high schools to identify and recruit students from underrepresented groups and underserved communities who could benefit the most from participating in the program. 


\section{Acknowledgements}

This project was supported by two grants from the US Department of Education: Minority Science and Engineering Improvement Program (MSEIP, Award No. P120A080080), and Hispanic-Serving Institution Science, Technology, Engineering, and Mathematics (HSI STEM, Award No. P031C110159).

\section{Bibliography}

1. Aud, S., Hussar, W., Planty, M., Snyder, T., Bianco, K., Fox, M., Frohlich, L., Kemp, J., \& Drake, L. (2010). The condition of education 2010 (NCES 2010-028). Washington, DC: National Center for Education Statistics, Institute of Education Sciences, U.S. Department of Education.

2. The Civil Rights Project. (February 14, 2012). Civil Rights Project reports call for fundamental changes to California's community colleges. (Press release). Retrieved December 2012 from http://civilrightsproject.ucla.edu/news/press-releases/crp-press-releases-2012/crp-calls-for-fundamentalchanges-in-californias-community-colleges

3. Shulock, Nancy \& Moore, Colleen (2010). Divided We Fail: Improving Completion and Closing Racial Gaps in California's Community Colleges. Retrieved March 2012 from http://www.csus.edu/ihelp/PDFs/P_DWF_11_10.pdf

4. National Science Foundation, Division of Science Resource Statistics (2011). Women, Minorities, and Persons with Disabilities in Science and Engineering, Arlington, VA, Retrieved March 2012 from http://www.nsf.gov/statistics/wmpd/pdf/nsf11309.pdf

5. Urban, J.,Reyes, M., and Anderson-Rowland, M. (2001). Minority engineering program computer basics with a vision, 32nd ASEE/IEEE Frontiers in Education Conference pp. S3C1-5 Retrieved December 2012 from http://fie2012.org/sites/fie2012.org/history/fie2002/papers/1060.pdf

6. Hobson, R, and Alkasawneh, R. (2009). Summer Transition Program: A Model for Impacting First-Year Retention Rates for Underrepresented Groups, ," in ASEE Conference \& Exposition, Austin, TX, 2009.

7. Besterfield-Sacre, M., Atman, C., and Shuman, L. (1997). Characteristics of Freshman Engineering Students: Models for Determining Student Attrition in Engineering," Journal of Engineering , vol. 86, pp. 139-150.

8. Fleming, L., Ldebetter, S., and Williams D. (2008). Engineering Students Define Diversity: An Uncommon Thread, 2008 ASEE Conference \& Exposition. Retrieved December 2012 from http://es21c.okstate.edu/resources/Publications/1039_ENGINEERING_STUDENTS_DEFINE_DIVERSITY $\underline{\text { A.pdf }}$

9. President's Council of Advisors on Science and Technology (PCAST). (2012). Engage to excel: Producing one million additional college graduates with degrees in science, technology, engineering, and mathematics. Retrieved December 2012 from: http://www.whitehouse.gov/sites/default/files/microsites/ostp/pcast-engage-toexcel-final_2-25-12.pdf

10. Davis, C.S, \& Finelli, C. ( 2007). Diversity and Retention in Engineering. New Directions for Teaching and Learning Journal, 2007(111), 63-71. 
11. Kuh, G. (2008). High-Impact Educational Practices: What They Are, Who Has Access to Them, and Why They Matter, Retrieved December 2012 from http://www.neasc.org/downloads/aacu_high_impact_2008_final.pdf

12. Derlin, R., \& McShannon, J. (2000). Faculty and Student Interaction and Learning Styles of Engineering Undergraduates, Retrieved May 2011 from http://www.eric.ed.gov/ERICDocs/data/ericdocs2sql/content_storage_01/0000019b/80/16/89/1d.pdf

13. Goldberg, J. \& Sedlacek, W. (1996), Summer Study in Engineering for High School Women, Maryland University, College Park, Maryland. Retrieved December 2012 from http://www.eric.ed.gov/ERICDocs/data/ericdocs2sql/content_storage_01/0000019b/80/14/b7/70.pdf.

14. Pantano, J. (1994), Comprehensive Minority SEM Programs at Santa Fe Community College, Paper presented at the Annual International Conference of the National Institute fo Staff and Organizational Development on Teaching Excellence and Conference of Administrators, Austin, TX, May 22-25, 1994.

15. Murphy, T. E., Gaughan, M., Hume, R., \& Moore, S. G. (2010). College graduation rates for minority students in a selective technical university: Will participation in a summer bridge program contribute to success? Educational Evaluation and Policy Analysis, 32(1), 70-83.

16. Raines, J. (2012). A Preliminary Review of the Effects of a Summer Bridge Program on Pre-College STEM Majors, Journal of STEM Education, 13(1), 22-29.

17. Allen, D., \& Bir, B. (2012). Academic Confidence and Summer Bridge Learning Communities: Path Analytic Linkages to Student Persistence, Journal of College Student Retention, 13(4), 519-548.

18. Stolle-McAllister, K. (2011). The Case for Summer Bridge: Building Social and Cultural Capital for Talented Black STEM Students, Science Educator, 20(2) 12-22.

19. Lenaburg, L., Aguirre, O., Goodchild, F., \& Kuhn, J. (2012). A Summer Bridge Program for Community College STEM Students. Community College Journal of Research and Practice, 36(3) 153-168.

20. CSU Office of the Chancellor (2011). Keeping Students in College: High-Impact Practices for Teaching and Learning, Retrieved December 2012 from http://www.calstate.edu/app/compass/documents/2011-KeepingStudents-in-College.pdf 
$\underline{\text { Appendix } 1}$

Summer Engineering Institute Typical Schedule: Week 1

\begin{tabular}{|c|c|c|c|c|c|c|c|}
\hline Time & Sunday & Monday & Tuesday & Wednesday & Thursday & Friday & Saturday \\
\hline 7:30AM & & Breakfast & Breakfast & Breakfast & Breakfast & Breakfast & \\
\hline \multirow{2}{*}{ 8:30AM } & & Campus & \multirow{4}{*}{$\begin{array}{l}\text { Project } \\
\text { Advisors } \\
\text { Project } \\
\text { Selection }\end{array}$} & \multirow{4}{*}{$\begin{array}{c}\text { Civil } \\
\text { Engineering }\end{array}$} & \multirow{4}{*}{$\begin{array}{l}\text { Engineering } \\
\text { Curriculum }\end{array}$} & \multirow{4}{*}{$\begin{array}{l}\text { Mechanical } \\
\text { Engineering }\end{array}$} & \\
\hline & & & & & & & \multirow{2}{*}{ Breakfast } \\
\hline 9:30AM & & \multirow{2}{*}{$\begin{array}{c}\text { Electrical } \\
\text { Engineering }\end{array}$} & & & & & \\
\hline 10:30AM & & & & & & & \multirow{4}{*}{$\begin{array}{l}\text { Field Trip } \\
10 \text { AM to } \\
3 \text { PM (bag } \\
\text { lunches) } \\
\text { Explorator } \\
\text { ium }\end{array}$} \\
\hline $\begin{array}{c}12: 00 \\
\text { PM }\end{array}$ & & Lunch & Lunch & Lunch & Lunch & Lunch & \\
\hline 1:30PM & & \multirow{4}{*}{$\begin{array}{l}\text { Guaranteed } \\
4.0 \\
\text { Workshop }\end{array}$} & \multirow{4}{*}{$\begin{array}{l}\text { Computer } \\
\text { Engineering }\end{array}$} & \multirow{5}{*}{$\begin{array}{l}\text { Field Trip : } \\
\text { PG\&E }\end{array}$} & $\begin{array}{l}\text { International } \\
\text { Wheelchair }\end{array}$ & Guest & \\
\hline 2:30PM & \multirow{2}{*}{$\begin{array}{c}\text { Registration } \\
\text { / Room } \\
\text { Check-In } \\
\end{array}$} & & & & Lab Tour & Speaker & \\
\hline 3:00PM & & & & & \multirow{3}{*}{$\begin{array}{c}\text { Communica } \\
\text { tions }\end{array}$} & \multirow{3}{*}{$\begin{array}{c}\text { Solar } \\
\text { Project }\end{array}$} & \multirow{3}{*}{$\begin{array}{l}\text { Personal } \\
\text { Time } \\
\text { /Laundry }\end{array}$} \\
\hline 4:00PM & \multirow{2}{*}{$\begin{array}{l}\text { Welcome } \\
\text { Ceremony }\end{array}$} & & & & & & \\
\hline 4:30PM & & $\begin{array}{c}\text { Team } \\
\text { Building }\end{array}$ & $\begin{array}{c}\text { Hands-on } \\
\text { Workshop } \\
\text { (CE) } \\
\end{array}$ & & & & \\
\hline 6:00PM & Dinner & Dinner & Dinner & Dinner & Dinner & Dinner & Dinner \\
\hline 7:30PM & Ice Breaker & $\begin{array}{l}\text { Homework } \\
\text { Time }\end{array}$ & $\begin{array}{l}\text { Project } \\
\text { Time }\end{array}$ & $\begin{array}{l}\text { Project } \\
\text { Time }\end{array}$ & $\begin{array}{l}\text { Project } \\
\text { Time }\end{array}$ & $\begin{array}{l}\text { Project } \\
\text { Time }\end{array}$ & \multirow{3}{*}{$\begin{array}{l}\text { Activity / } \\
\text { Movie } \\
\text { Night } \\
\text { (SC 256) }\end{array}$} \\
\hline 9:00PM & $\begin{array}{l}\text { Personal } \\
\text { Time }\end{array}$ & $\begin{array}{l}\text { Personal } \\
\text { Time }\end{array}$ & $\begin{array}{l}\text { Personal } \\
\text { Time }\end{array}$ & $\begin{array}{l}\text { Personal } \\
\text { Time }\end{array}$ & $\begin{array}{l}\text { Personal } \\
\text { Time }\end{array}$ & $\begin{array}{l}\text { Personal } \\
\text { Time }\end{array}$ & \\
\hline 10:00PM & In Rooms & In Rooms & In Rooms & In Rooms & In Rooms & In Rooms & \\
\hline $10: 30 \mathrm{M}$ & Lights Out & Lights Out & Lights Out & Lights Out & Lights Out & Lights Out & In Rooms \\
\hline
\end{tabular}




\section{Appendix 1 (Continued)}

Summer Engineering Institute Typical Schedule: Week 2

\begin{tabular}{|c|c|c|c|c|c|c|}
\hline Time & Sunday & Monday & Tuesday & Wednesday & Thursday & Friday \\
\hline 7:30AM & & Breakfast & Breakfast & Breakfast & Breakfast & Breakfast \\
\hline 8:30AM & Breakfast & \multirow{3}{*}{ Math } & \multirow{3}{*}{$\begin{array}{c}\text { Computer } \\
\text { Applications: } \\
\text { CAD }\end{array}$} & \multirow{3}{*}{$\begin{array}{l}\text { Robotics } \\
\text { Challenge }\end{array}$} & \multirow{3}{*}{ Project Time } & \multirow{3}{*}{$\begin{array}{l}\text { Presentation } \\
\text { (SCI-101) }\end{array}$} \\
\hline 9:30AM & $\begin{array}{c}\text { Personal } \\
\text { Time }\end{array}$ & & & & & \\
\hline 11:00AM & \multirow{4}{*}{$\begin{array}{c}\text { BBQ } \\
\& \\
\text { Fun Games } \\
\text { (Softball } \\
\text { Field) }\end{array}$} & & & & & \\
\hline 12:00PM & & Lunch & Lunch & Lunch & Lunch & $\begin{array}{c}\text { Awards } \\
\text { Buffet }\end{array}$ \\
\hline $1: 30 \mathrm{PM}$ & & \multirow[b]{2}{*}{ Student Panel } & \multirow{2}{*}{$\begin{array}{l}\text { Guest Speaker } \\
\text { (Financial Aid) }\end{array}$} & \multirow{5}{*}{$\begin{array}{l}\text { Field Trip } \\
\text { Bay Bridge }\end{array}$} & \multirow{4}{*}{$\begin{array}{c}\text { Mock } \\
\text { Presentations } \\
\text { Post- } \\
\text { Program } \\
\text { Survey }\end{array}$} & Luncheon \\
\hline 2:00PM & & & & & & $\begin{array}{c}\text { Checkout } \\
\text { time }\end{array}$ \\
\hline 3:00PM & \multirow{3}{*}{ Project Time } & Planetarium & \multirow{3}{*}{$\begin{array}{l}\text { Workshop: } \\
\text { Robotics }\end{array}$} & & & \\
\hline 4:00PM & & \multirow{2}{*}{$\begin{array}{l}\text { Project Progress } \\
\text { Report - } \\
\text { Meeting with } \\
\text { Project Advisers }\end{array}$} & & & & \\
\hline 5:00PM & & & & & $\begin{array}{c}\text { Personal } \\
\text { Time }\end{array}$ & \\
\hline 6:00PM & Dinner & Dinner & Dinner & Dinner & Dinner & \\
\hline 7:30PM & \multirow{2}{*}{$\begin{array}{l}\text { Personal } \\
\text { Time }\end{array}$} & Project Time & Project Time & Project Time & \multirow{3}{*}{ Talent Show } & \\
\hline 9:00PM & & Personal Time & Personal Time & Personal Time & & \\
\hline 10:00PM & In Rooms & In Rooms & In Rooms & In Rooms & & \\
\hline $10: 30 \mathrm{PM}$ & Lights Out & Lights Out & Lights Out & Lights Out & In Rooms & \\
\hline
\end{tabular}

